\title{
The Dialogue between the (Self) and the (Other): Analysis of Arab-American Dialectical Relation
}

\author{
Amani G. Jarrar \\ Associate Professor, Philadelphia University
}

\begin{abstract}
The 'Self' and the 'Other' are two philosophic concepts that are represented in this study to reflect upon the relations between East and West, considering in particular the dialectical relation between Arabs and Americans. Analysis of selected history events introduces such inter-relations being mainly described on the basis of colonialism, terrorism, and peace on the other hand. Arab-American relations were questioned in the Arab region, where Arabs considered the relation in terms of American polarization as dominant and supporting the Jewish presence, which is mainly the reason behind the cultural clash that ended into a clear political clash by the rejection of the Deal of the Century. The study concluding that Arabs were used to decades of rejecting and denying the (other) in different stages of history because of their cultural heritage ; and that they should rather now reconsider their standings to make it more humanitarian seeking peace rather than hatred and violence .
\end{abstract}

Key words: The 'Self' and the 'Other', Arab, American, colonialism, terrorism, peace, Arab-American relations, Arab region, American polarization, Jewish presence, Deal of the Century.

DOI: $10.7176 / J L P G / 86-18$

Publication date:June $30^{\text {th }} 2019$

\subsection{Introduction}

The (self) and (other) are two different terms that represent two different psychological states of mind. In this context, the (self) is taking full cognition of the other as a totally different entity that may either accept or reject the (other). In this study, the (self) represents Arabs, being in conflict with the (other), which represents America. Many examples are taken from historic events that were analyzed to discover the roots of clash between both cultures.

The world is facing today a new era of (unipolarity), where the United States of America led the system of international political interactions. It intervened in the affairs of the various countries of the world for different causes, particularly the Arab world, by introducing economic and humanitarian projects aimed at serving their interests first and the interests of their allies.

The dialectic of American-Arab relations has been the focus of researchers, politicians and historians who are characterized by an active memory with a critical vision that is based on reflection on all events in the world. But what is required is to reach a future vision to deal with the challenges of the Arab world by asking questions aimed at scrutinizing, based on critical judgment and historical documentation.

This research is an attempt to understand the relation between the (self) and the (other), namely America, with a flashback to Europe and the Ottomans, where the relations between Arab, Turkish and Ottoman people were the beginning that formed a stereotype of Arab communication with the (other).

It is necessary to study several writings on such relations, particularly the book (We and America) (Gharaybeh, 2009) that was written in Arabic except the last chapter in English, it is considered in the Arab world as a model reflecting those relations. In this research, the history-based approach was adopted concentrating on analysis and 
historical linkage of events. The first part of this research is the study of the beginning of the American presence in the Arab region and the launching of strategic initiatives to serve its interests. That historian reveled in his book the tension between the Arab position and the American methodology, trying to shed a perspective for the future of Arab relations with the (other), led by hopes and aspirations to achieve peace.

Therefore, the nature of these relations is discussed with an emphasis on their effects on our present and future reality. It is worth highlighting America as the ( unipolarity ) of the world's political forces. It must therefore be studied in depth from all its geopolitical aspects, including the role of the military in guiding American policy, and the impact on identifying and understanding its relations with its Christian neighbors and the world, particularly, with the Arab Maghreb, the Levant and the Arabian Gulf. (Potter, 1972)

\subsection{Problem Statement and study questions}

The study introduces a major problem that faces the Arab Mind. The Arab- American relations are problematic to discuss, it reflects the dilemma between the East and West, the clash between both civilizations. The study raises different questions to reveal the dialectical Arab- American relation. It points out the cultural and political dimensions behind the clash between the (self) and the (other).

The study raises the following questions to answer the problem statement:

- How does the relation between the (self) and the (other) in the Arab Mind reflect the Arab- American relations?

- How does the American presence manifest in the Arab region?

- How does the American position on the Jewish presence in the Arab region affect the Arab- American relations ?

- What is the Arab position on American policies?

- Can Arabs formulate a new vision for the future of Arab-American relations?

\subsection{Study Methodology}

The study uses the analytical methodology to answer the previous questions. The methodology used is to handle the nature of such questions that reflect the philosophic complicated problem in the cognition of the Arab Mind, to deal with clashes between the (self) and (other), trying to understand the Arab- American relations.

\section{4 literature illustrating the relationship between Arabs and America}

Many books handled the different Arab- American relations, perhaps the most argumentative is the book entitled "We and America" that was written by the Jordanian thinker Abdul-Karim, which is in 208 pages with an introduction and six chapters, followed by chapter seven that was written in English, including an article on models of Islamic governance systems, its policies, with brief historical narration.

As a neutral critique, I can see how that writer couldn't hide his subconscious hatred that was deeply rooted in his Islamic culture, despite the need for the work of historians who need to be neutral with no dominating feelings of prejudice, intolerance and hatred, but one can clearly see how contradictory feelings of hatred and admiration emerged in several parts of the book to describe the US as a snake. Gharaybeh presented the US as brutal more than the Mongols, even considering the later as enemy of humanity. He thinks that the Arabs, the English and the French people did not know how to deal with America to protect humanity from such authoritarian pollution. (Kabha,2006).

Views differ in evaluation of the different successive presidents on USA. While some believe that the current President Donald Trump is hostile to the Arabs based on his decision to move the US embassy to Jerusalem declaring it as the capital of Israel, while others recognize Obama's position ,hoping for a new foreign policy, especially after the decline of the status of America under the former Presidency of George W. Bush (Telhami, 2018)

Some political writers see Donald Trump as facing many internal problems with priority, caring the less for the Arabs, focusing mainly on the strategic goals of America, maintaining its dominance and superiority in the world, protecting alliances that help in monopolizing the world, while paying attention to the US role in dominating and interfering in the Arab region and the world, through his alliance with Israel. On the other hand, 
some believed that Obama did not have a specified political doctrine in the field of foreign policy; so that his doctrine which was based on reducing American involvement abroad with an emphasis on the interior, led to deterioration in the US role in foreign affairs and especially in the Middle East. Others believed that both didn't make a real shift towards a new regional peace initiative in the Middle East, claiming that all US presidents are under pressure from successive members of the Congress to encourage Arabs to normalize with Israel. And some members of the US House of Representatives asked various presidential departments to recognize Jerusalem as the capital of Israel and to transfer the US embassy from Tel Aviv to Jerusalem; they also often draw criticism of any decision leading to freeze Israeli settlement activities. The political support of Israel continues from different presidencies, and perhaps this is what negatively affected relations with the Arabs in general, particularly the refusal of American presidents to consider Israel as responsible for the crises in the Middle East. In this regard, the American thinker Professor Noam Chomsky pointed that Obama, for example, did not make any change in military aid to Israel and did not stop the flow of expenditures to Israeli settlements in Palestine (Scudder,1998)

Unfortunately, it seems that Arabs generally have a severe bias against America that may reach the level of hatred in many cases, and this contradicts with the fact of Arabs desire to emigrate to live in welfare as the American people, and it also seems that Arabs differ in their attitudes towards the US administration or the American people.

For example, the visit of the twenty-sixth President Theodore Roosevelt during his reign (1901-1909) to the city of Aswan in Egypt was meant to congratulate the Egyptians for the English occupation, which abolished their parliament and restricted the freedom of their ruler, The Egyptians were surprised by his words ,so that Arab poet Ahmed Shawqi responded in prose and verses of poetry.

The research in this regard addresses some of the terms related to the dialectical situation experienced by Arabs and discusses the implications of certain states such as terrorism, and democracy in the Middle East.

Many references are used by Arab thinkers to study the state of Arabs under the Ottoman era, such as the article on Arabs under Ottoman and American rule that was written in English by the author Abdul Malik Khalaf Tamimi to discuss evangelization in the Gulf region ( Scudder,1998) (Kuwait 1982).

An article on American relations with the North African countries was written on the diplomatic relations between the States of Morocco and the United States of America 1776-1816.(Roberts,1999) In addition to the letter Churchill, who warned about the source of evil (Ramadan al-Shallash, Mustafa Kemal, Lenin), who were considered as anti-Western civilization in 1920. Ramadan al-Shallash was born in Damascus in 1951. He accompanied Prince Abdullah in his visit to Jerusalem in 1921, where he met Churchill there. That may be taken as reference for such relations (Huntington, 1996).

It is worth investigating here the origin of Western hostility to the Arabs from Arabs' point of view .In addition to the previous reference, a number of Arab and thinkers from the East part of the and the world believe that the Jews have a role in activating this hostility, adding what the Arab thinkers see in many cases expressing the role of racial and religious intolerance that dominates Western thought in general and American in particular.

We can support the previous political analysis when referring to political documents, such as the oldest agreement between the Kingdom of Morocco and America, and by checking the list of persons accused of hijacking the four American planes in the incident of September 11, 2001, led by bin Laden and other nineteen Arabs, in addition to the report of the US Consul for American settlements in Palestine in 1866.

The history of the United States of America can be studied since its discovery in 1492, revealing the changes in the North American population during the period (1750-2004), so that population changes from North and South America since its founding in 1790 .

And to study the Arab relations with America, we must study the most prominent events in the history of the United States since its discovery in 1492, and perhaps the US invasion of Iraq in 2003.

In studying the personalities of the presidents of the United States, we recognize that two of them were awarded the Nobel Peace Prize: Theodore Roosevelt (1901-1909) and Woodrow Wilson (1913-1921), although they were involved in war. (Francis, 1974). The Arab relations with Turkey are considered to be typical of the interaction between the Arabs and the West, where the historical heritage of Turkey and the Ottoman Empire history shows 
the beginning of the Turkish presence and how Arabs were used as soldiers. Arabs were in deterioration in Iraq and Iran, but Arab historians recognized their misfortunes because of the Seljuk's empire' enthusiasm for fighting the Shiites, and the Byzantines. Arab historians realized how Arabs were under the rule of the Turkish Mamluk dynasty and Caucasian, which was the strangest thing in the era of Turkish-Arab participation. It is bizarre too how some historians praised such rulers, for their good and the righteous acts, in the same time they were inclined to shed blood. This is the legacy of Ottoman history, whose impact remains constant on Arabs' history. (Belden, et al, 2008). Therefore, Arab-American relations may be summarized as follows:

\subsubsection{Arab -American relations}

Arab historians believe that the American political entity and American society came as an extension of the European community, which was originally looking for gold and silver. Europeans continued to grow; they viewed colonialism as a liberation movement. European colonies formed administrative units that refused to integrate in the eastern part of United States. In 1774, the American Revolution began to succeed in gaining recognition of its independence in 1783. After the inauguration of George Washington as its first president in 1789, America made its policy based on secularism and democracy. America followed the European approach to dominate Arab countries. Europeans described American's history of adventurers as predatory capitalism (Said, 1995).

The American military's attempts to dominate and guide American policy continued to emerge during the Cold War with the Soviet Union. The American military alliances began with the Rio coalition of the American States in 1941 and the North - Atlantic alliance in 1948, the Baghdad Pact in 1955, and the G8 summit in 1975.(Francis, 1974; Henrikson,1980; Ashton,1993; Kirton, 2017) After the collapse of the Soviet Union, the American polarity emerged, which adopted in its expansionist policy on its armed forces. And in its military attempts to control power, where President Harry Truman restrained the domination of the American General (MacArthur), who ruled Japan since 1945-1951, risking the issuance of the order to remove him from power in 1951 after criticizing the US administration for refusing to attack China during North Korea's invasion of South Korea (Higgins, 1960).

The Arab and public writers have confirmed their view of America and their rejection because of the wars it fought since the War of Independence in 1775 until the war in Iraq in 2003. Statistics indicate the extent of the devastation caused by the wars of dead, wounded and disabled as well as the victims of the raids of its aircraft civilians. Some Arab writers see the Indians as the greatest example of the history of American aggression, leaving only less than three million Indians, including the people of Alaska and Hawaii (Ashton, 1993).

The Arab intellectuals believe that Dick Cheney, one of those who participated in the scenario of the attack on Iraq and was the director of Halliburton, that oil is the most important determinant behind the war on Iraq not only to satisfy the immediate need for America, but as a tool for global control to reduce the burden on the economy , as the American economist Joseph Stiglitz, who has declared several advisory and administrative positions, as discussed in his book "The Three Trillion Dollar War - The True Cost of the Iraq Conflict" , declaring that the control of Iraqi oil would cover the cost of war and generate additional profits (Bilmes, 2008).

\subsubsection{American presence in the Arab region}

America's situation can be described as difficult to solve. In an attempt to understand this complicated situation, we can turn to the Associational approach as well as the political analysis of historical facts, and follow American initiatives with expansionist objectives in the Maghreb, the Levant and the Gulf.

Arab writers believed that American society inherited hostility and the European sense of superiority, which goes back nearly five centuries. In the story of the judge of Cordoba (Abu al-Qasim al-Andalusi,) in his book on Nations, declaring the reason for the aggression of the (Other), due to the colonial expansion of the west as a movement for emancipation and restoration of truth (Attar, 2005). Perhaps this statement highlights the misunderstanding and prejudice of the Arabs against the Americans as stated in literature and history. On the other hand, it is not just a colonial movement; this is rather interpreted as Europe having the right to liberate the Barbarian people governed by tyrant rulers, showing their interest to free them. America's leaders followed this approach, which the Arabs regarded as supremacy and colonialism in dealing with their neighbors, while the Americans considered it as liberation. The Arabs believed that America had pursued its expansionist policy driven by economic factors. So that Theodore Roosevelt congratulated the Egyptians on the blessing of the English occupation in 1910 and that is considered by Arabs as a proof of the American colonialism (Kirton, February). 
The Arab writers believed that America's greatest concern was to raise the conflict in Arab, Muslim and Christian societies, where they sought to evangelize Arabs and Arabize Christianity. Their interest in pre-Islamic literature emerged as an attempt to prove that most poets were Christians, so they began to Arabize Christianity, starting with translating the Bible, trying to establish a Christian community and therefore Christian Arab literature. The Americans recognized the importance of Christianity preaching in the Arab world, so they set up printing presses; they established a printing press in Malta and a school in Beirut in 1822. The American University of Beirut was established in 1919 and converted to teaching English directly after Egypt was subject to the British mandate with the consent of the United States. The missionaries started translating the Bible because of the absence Christian prayers in Arabic, and according to Arab Muslims ,this missionary movement resulted in particular to graduating young generation of intellectuals who are skeptics and materialistic (Attar, 2005).

Arabs believed that the American-Libyan War (1801-1805 was most conspicuous, they believed in US conspiracies against the North African countries (Algeria, Tunisia and Tripoli).Arabs believed that Jefferson claimed pressure on Christian countries to take anti-Arab positions, particularly after assuming the post of President of the United States on the fourth of March in 1801 , with the implementation of his policy of hostility resulted in the outbreak of war between America and Tripoli on the fourteenth of May in 1801.

In the mind of Arabs these are considered conspiracies, so that Morocco have been a pioneer in providing assistance to America, where the Moroccan Sultan (Mohammed bin Abdullah Ismail) offered the Moroccan Atlantic ports to the American ships and began to recognize them as an independent state. However, America did not appreciate that initiative and the Sultan almost turned against America without the intervention of the King of Spain, who wanted to seek again to win the friendship of Morocco, the Sultan agreed to a treaty concluded in 1786 between the US Consul General Thomas Barclay, who was the ambassador to King Mohammed, where negotiations were held. It is thought that the US policy of aggression against Algeria and Tunisia continued during the reign of US President James Madison.

It is worth highlighting the Arab countries where the naval American officer William Lynch visited Jordan and Palestine in 1848, where the mission led by Lynch to the Dead Sea and Kerak to study the establishment of a national homeland. Jordanian historians like Abd al-Karim al-Gharaybeh believed in the hostile and superlative position of Americans. He believed that that campaign was meant to transfer the Christian and Muslim savage population to realize the idea of the Promised Land. After Lynch's 20 years official tour during the American Civil War, a Christian-American trip was made to the south of Jaffa to establish a colony there (Lynch, 1850).

It is interesting to see how Arabs think that the scientific movement and scientific research and the economic breakthroughs are the real reason that led America to attack Iraq in 2003, so that is how Arabian Gulf treaties are held.

As for Egypt, America's interest in it came late. Isma'il Pasha used the American military in his military campaigns in Sudan. In one of his campaigns led to America, where Arabs believed that the Americans betrayed his religion and Al-Ahbash caused the defeat of the Egyptian army. So that Britain supported the US colonialist approach with its operations in Tripoli, and Algeria. Arabs believed that Americans exerted pressure on the rulers in Oman and the Gulf to accept missionary mission activity despite its misconduct in many cases. (Kabha, 2006)

The US President Thomas Jefferson chairing the military committee in the Senate, ordering the use of camels in the military campaigns in the West and during the civil war, where $\$ 30$ thousand were allocated for the purchase of camels, led by Navy Lt. David Dixon Porter to the Mediterranean Sea for the bold use of the camel's weapon by the US Army, where the American ship was lead to Egypt for the purchase of 33 camels, after their failure to purchase in Tunisia because the Ottomans used it in the Crimean War (West,2018).

Many Arab intellectuals have rejected American practices towards the world, condemning the global attitude towards such practices, particularly the genocide and displacement caused by America in Afghanistan, Iraq, Palestine and Vietnam (Henrikson, 1980)

The issue of terrorism, which most Arab intellectuals have accused America of, saying that they invented personalities such as Bin Laden who was part of the al-Qaeda organization, in order to convince the world, with the danger of terrorism, and the importance of fighting terrorism and extremism. Unfortunately, many Arab thinkers committed intellectual fallacies stemming from hatred of the (Other). Terrorism was defined particularly 
as a term invented by the West, as its representatives and its implementers, suggesting it is designed by the West as the oppressors with Western interests and Western arrogance, as described by Arabs.

But an objective Arab thinker must admit that the name of America, which is known for freedom and progress and became the most powerful nation in the world, and become a destination for seekers of liberty. In this context, unfortunately, every Arab who seeks freedom is accused of treachery, so that the Arab thinkers who support American liberal thoughts accuse Americans of being deeply hostile to the regimes in their countries.

\subsection{The American position on the Jewish presence in the Arab region}

In reviewing American practices in the Arab world, Arabs considered the worst actions by America towards the Arab world as creating the Jewish state that was governed by an intelligence apparatus that placed itself at the service of the most powerful state in the world. Jews were not interested in the beginning of their presence in America as it is today; when the Jews of Andalusia arrived with the Dutch in 1654 accompanied by Jewish migration to New Amsterdam with other European groups, which became New York. Their number later increased to a quarter of a million in (1913-1920), where Jews grew up in European and American politics. The Jewish vote in the 1912 elections, brought Wilson to presidency; he believed in the right of white peoples to liberate themselves; he made (Brands) the first Jewish member of the Supreme Judicial Council. Wilson's interest in the Jewish national homeland increased. In March 1918, he issued a letter to Weizmann stating his support for a Jewish national homeland in Palestine, supported by 69 senators and 31 Parliament members. He endorsed the formula of the Balfour Declaration ("Balfour's promise" in Arabic), that was a public pledge by Britain in 1917 declaring its aim to establish "a national home for the Jewish people" in Palestine. It was known as the promise of those who don't own to those who don't deserve. Later, America used the Jews in its powerful intelligence apparatus, which relied heavily on them, as well as minorities who resorted to America in search of freedom. These minorities were characterized by hatred from the Arab perspective, which was an obstacle that affected relations with neighboring countries. The Baltic communities of Estonia, Latvia, and Lithuania exercised power for America, and that led to the tension of relations with the Soviet Union. Most Arab thinkers believe that America is biased toward the Jews, and others exaggerate their belief in Jewish control over US policy. Most Arabs believe to some extent that America has inherited the ancient hatred of Europe against the Arabs and Muslims.

What is happening today in Palestine is basically, the American plan of Sharon turned Palestine into a field of American experiences in which the Jews conducted their military operations.

\subsection{The Arab position on American policies}

The Arabs could not effectively deal with the Jewish state, blaming America of being the cause of its expansion in the middle-east. The attitude of the Arabs toward the American-Arab approach was in the context of refusing the wave of European colonialism in the Arab region. Unfortunately, many Arab Muslims called for jihad and armed struggle from Islamic perspective. The problem appeared in their considering jihad as non-violence. The position of the majority of Arabs is really difficult and complex, so that they cannot earn America's friendship because of their religious references and education, which implants hatred in their minds for the other.

We cannot fail here to refer to the view of many Arab thinkers of American policy towards the world as representing a state of racism, hostility and superiority.

Arabs revealed a special position towards Zionism, so that some writers like Gharaybeh referred to that as cultural awareness in sensing the Zionist danger. Following Balfour Declaration on November 21, 1917, the Arabs in America felt the danger of Zionism, so that they formed the Palestinian Society to resist Zionism, and a series of studies on the Palestinian cause was published in 1919 to create pressure on the British government. The efforts of the Palestinians in America were clear, which the Arabs mistakenly believed has also encouraged immigration aiming at killing their national affiliation. So they followed an Arab-Islamic union that played an important role in influencing America's internal policy.

The Arab Revolt or Great Arab Revolt was officially initiated by Hussein bin Ali, Sharif of Mecca, who also sought to take advantage of the principles of Wilson in his struggle with the England, so that he corresponded with Wilson in order to recognize the Arab Kingdom ; he stressed the non-inclusion of non-Arab races to the Arab state .Then the statement of the representative of Hijaz Prince (Faisal bin Al- Hussein) in the Peace conference in 1919 was to confirm the desire of his father in the Arab kingdom rejecting the Balfour Declaration. 
As for peace as quested by Europe, the Arab intellectuals, showed in their writings that peace is not the priority of Americans as much as the presence of Israel in the Arab region and the Arabs acceptance of their existence as an intelligence apparatus.

\subsection{Perspective vision for the future of Arab-American relations}

To be fair enough, the call for peace and love was limitlessly seen in the writings of Arab thinkers, the bias of the majority of Arab writers was strongly clear towards America. Whereas, I frankly believe that many Arab thinkers mistakenly considered Islam as tolerant and peaceful.

Today, the "Deal of the Century", as presented by Donald Trump to the Middle East , on December 6, 2017, reflected America's recognition of Jerusalem as the capital of Israel. Since officially presiding in 11/2016, many leaks were recognized concerning Trump's strategy of the Arab-Israeli conflict settlement. Arabs believed that the most important issues that he wished to remove from the negotiating table are the issues of Jerusalem and refugees, followed by the issue of the establishment of a Palestinian state devoid of sovereignty and authority.And that is considered as the main theme of disagreement between America and the Arab politicalIslam.

In shedding light on Trump's position on the issue of the conflict between the two parties (the Israeli and the Arab) during the presidential elections of February 27, 2016; where he showed neutrality when asked about his position on the Palestinian-Israeli conflict. Trump declared that to achieve peace between Israel and its neighbors, the negotiator or mediator should not adopt a position against another, or to classify a party as good or bad. In reference to the apparent neutrality of Trump during the televised debate, political analysis confirmed that the Zionist lobby and the pro-Israel evangelicals could be mad of him. Trump certainly does not need to consolidate his relationship with Israel, as he is known to be a strong supporter of Israel , and his advisers in the Middle East sympathize with the Israeli right. But Trump's move to move the US embassy to Jerusalem was considered useless for US policy in the Middle East.

In order to confront the (other), as represented in Europe and America, many Arab intellectuals unfortunately call for the boycott of America according to the interests of the Arabs economically and culturally. So that many Arab thinkers criticized some refugees who were complaining of distress in their countries, so they immigrated to America, preferring their individual freedom to the liberty of their countries, forgetting their basic human rights.

I hereby recall King Hussein speech at the University of Jordan in 1974. History should not be a burden or vice versa. Arab should rather be wise in their relations of friendship away from hostility and boycotting, so that they should not allow any distorted emotions that were planted in their minds, especially manifested in their rejection of the (other), since that would harm the future of the Arab nation.

Therefore tolerance can solve the existential problems of international relations from a human perspective. Terrorism cannot be resisted by terrorism. Hence, comprehensive disarmament of nuclear weapons and the fight against violence must be sought for peace.

\subsection{Conclusions}

- Arabs should be aware of the importance of international relations. They should also reconsider their relationship that reflect dialogue between the (self) representing (Arabs) and the (other), represented by diversity of people throughout history, such as (Turks and Ottomans), Europeans, Americans and Israel as such.

- Arabs need to adopt a new paradigm shift and rather send a different humanitarian message to the world based on the renunciation of all forms of violence ,hatred and racism.

- Arabs need to rethink and rewrite human history in a way that promotes peace building.

- Arabs first duty should be calling for peace and renouncing hostilities. Arabs should concentrate on the present and dream of a better future rather than reliving the past thinking of its glories, especially that Arab history distorted the facts; it suffered from the problem of hatred of the (other).

- Arabs should rather focus on the interest of the Arab nation today which is more important than its history, and the future is more important than the present. I hereby propose that the Arab history must be rewritten in order to reconsider the inherited hatred, warlike manners and violence, so that Arabs should rather move towards building peace. 
- The desired history Arabs should seek is that human history based on human relations, making respect for others and equality as its foundation and basic rule of international law, so that Arabs should denounce hatred to be the main engine of their international relations.

- As education is the basic means for progress, it is necessary to rethink educational curricula in the middle east order to be able to change the intellectual Arab mind .

\section{References}

Ashton, N. J. (1993). The hijacking of a pact: the formation of the Baghdad Pact and Anglo-American tensions in the Middle East, 1955-1958. Review of International Studies, 19(2), 123-137.

Attar, S. (2005). Conflicting accounts on the fear of strangers: Muslim and Arab perceptions of Europeans in medieval geographical literature. Arab studies quarterly, 17-29.

Belden, L. E., Stiglitz, J. E., \& Bilmes, L. J. (2008). The three trillion dollar war: the true cost of the Iraq Conflict. Principios: estudios de economía politica, (12), 115-122.

Francis, M. J. (1974). The United States at Rio, 1942: The Strains of Pan-Americanism. Journal of Latin American Studies, 6(1), 77-95.

Gharaybeh, A.(2009).We and America (Arabic version),Dar Ward.

Henrikson, A. K. (1980). The Creation of the North Atlantic Alliance, 1948-1952. Naval War College Review, 33(3), 4-39.

Huntington, S. P. (1996). The Clash Of Civilizations And The Remaking Of World Order, 367 pp. New York: Touchstone.[Extreme realist position. Uses the lens of realism to understand culture.].

Kabha, M., \& Erlich, H. (2006). Al-Ahbash and Wahhabiyya: Interpretations of Islam. International Journal of Middle East Studies, 38(4), 519-538.

Kirton, J. (2010, February). Assessing G8 and G20 Performance, 1975-2009. In International convention of the International Studies Association, New Orleans (pp. 1-4).

Lynch, W. F. (1850). Narrative of the United States' expedition to the river Jordan and the Dead Sea. Richard Bentley.

Potter, A. R. (1972). The Truman-MacArthur Controversy: a Study in Political-Military Relations. ARMY COMMAND AND GENERAL STAFF COLL FORT LEAVENWORTH KS.

Roberts, P. H., \& Tull, J. N. (1999). Moroccan Sultan Sidi Muhammad Ibn Abdallah's Diplomatic Initiatives Toward the United States, 1777-1786. Proceedings of the American Philosophical Society, 143(2), 233265.

Said, E. W. (1995). Orientalism: Western Conceptions of the Orient, with a new Afterword. Penguin Books.

Scudder, L. R. (1998). The Arabian mission's story: in search of Abraham's other son (No. 30). Wm. B. Eerdmans Publishing.

Telhami, S. (2018). Why Is Trump Undoing Decades of US Policy on Jerusalem? The Washington Report on Middle East Affairs, 37(1), 8-13.

West, R. S. (2018). The Second Admiral: A Life of David Dixon Porter, 1813-1891. Pickle Partners Publishing. 